\title{
Characterization and application of Lippia alba (Mill) and Cymbopogon citratus D.C. Stapf. essential oils as natural sanitizers in coriander
}

\author{
Amanda Beatriz Sales de LIMA ${ }^{1 *}$ (D), Inês Maria Barbosa Nunes QUEIROGA², Gabriela Muricy de Souza SILVA', \\ Jessyka Silva da COSTA ${ }^{1}$, Jossana Pereira de Sousa GUEDES³, Cybelle de Oliveira DANTAS ${ }^{3}$, \\ Mônica Tejo CAVALCANTI ${ }^{1}$
}

\begin{abstract}
Essential oils (EOs) are a promising alternative for food preservation and can be used instead of synthetic antimicrobial compounds such as sanitizers, as long as they are efficient and safe. In view of this possibility of use, Lippia alba (Mill) (LAEO) and Cymbopogon citratus D.C. Stapf. (CCEO) essential oils were evaluated as natural antimicrobials and applied into coriander for its biocontrol. The EOs were extracted and their physical properties, total phenolics, cytotoxicity to Artemia salina L. and antimicrobial potential in vitro and on natural coriander microbiota were determined. The EOs had a LD50 (median lethal dose - checked), are considered biologically active. MIC (Minimum Inhibitory Concentration) varied from 1.25 to $5.00 \mu \mathrm{L} / \mathrm{mL}$ and from 0.62 to $5.00 \mu \mathrm{L} / \mathrm{mL}$ for LAEO and CCEO, respectively, on standard strains of Staphylococcus aureus, Salmonella Thyphimurium, Salmonella Enteritidis, Escherichia coli and Listeria monocytogenes. The lowest MIC values for LAEO and CCEO were selected for application in coriander. EOs reduced the pathogenic microbial load in the coriander revealing its potential as a natural sanitizer, and thus demonstrating superior or equivalent efficacy to commercial sanitizer. By correlating the cytotoxic and antimicrobial results obtained, we have shown that these EOs present potential for application in foods.
\end{abstract}

Keywords: coriander; antimicrobial activity; cytotoxicity; biocontrol.

Practical Application: Food safety control as a natural food sanitizer.

\section{Introduction}

The food industry has been increasingly challenged by greater legal requirements to ensure food and consumer safety. In contrast to synthetic compounds, which are often not completely efficient or which can have toxic effects on consumers' health (Gómez-López et al., 2008), natural antimicrobial agents have been gaining prominence as a market trend, mainly because they are seen as an alternative to using these sanitizers (Souza et al., 2009; Azerêdo et al., 2011; Sousa et al., 2012; Oliveira et al., 2015).

Essential oils (OEs) are complex, volatile, lipophilic natural compounds characterized by a strong odor. These compounds are composed of different classes, mainly monoterpenes, sesquiterpenes and oxygenated derivatives, which can vary in quantity, quality and composition according to the climate, soil composition, plant organ, age and stage of the vegetative cycle (Bakkali et al., 2008; Valeriano et al., 2012; Tohidi et al., 2017). They are produced by plants as secondary metabolites and known for their medicinal properties; their antimicrobial potentials on deteriorating and pathogenic microorganisms in foods stand out, as well as promoting benefits to various food matrices (Bakkali et al., 2008).

As alternatives to plants that produce EOs in satisfactory quantities, we can highlight Lippia alba (Mill.) (LAEO; bushy matgrass, a.k.a. "erva cidreira" in Brazil), whose major chemical components are citral, carvone and myrcene (Oliveira et al., 2006; Jezler et al., 2013), and which has bioactive potential with proven effects of antimicrobial, toxicity, repellency and antiparasitic activity (Aguiar et al., 2008; Peixoto et al., 2015; Oliveira et al., 2008; Soares et al., 2016); also, Cymbopogon citratus D.C. Stapf. (CCEO; lemon grass) which contains EO rich in citral, myrene, neral, geranial and other compounds (Lermen et al., 2015; Bassolé et al., 2011) with antimicrobial (Leite et al., 2016), antioxidant and anti-inflammatory properties (Guimarães et al., 2011; Boukhatem et al., 2014). There have been reports in the literature on the use of Lippia organoides Cham. (alecrim pimenta) essential oil in micro-organisms of animal products (Queiroz et al., 2014; Almeida et al., 2016) and of the inhibition potential of Cymbopogon citratus D.C. Stapf. against pathogenic microorganisms in pineapple juice (Leite et al., 2016). In this context, we highlight the practical potential of applying these EOs as an alternative for controlling microorganisms.

Studies of the antibacterial activity of EOs against foodborne pathogens have been carried out mainly in vitro, and more recently in food matrices such as the EOs of Mentha piperita L., Cymbopogon citratus D.C. Stapf., Origanum majorana and Ocimum basilicum (Valeriano et al., 2012). Their cytotoxic characteristics have also been studied (Sharma, et al., 2009) in 
order to understand their effects on bacteria, which appears to be related to their ability to cause damage to the cell wall, since typical lipophilic compounds can go through cell walls and the cytoplasmic membrane, affecting its structure and making it permeable (Burt, 2004; Bakkali et al., 2008). Prior to any substances being indicated for use in foods, it is important that they are all evaluated for risk in order to ensure the safety of the product to consumer's health (U. S. Food and Drug Administration, 2017).

Among the vegetables widely consumed in natura and susceptible of contamination, we can emphasize coriander (Coriandrum sativum L.) (Oliveira et al., 2015). Coriander is a little studied herb, although it is consumed almost all over the world due to its excellent nutritional characteristics in cooking, high vitamin content, medicinal properties, and its considerable value and socioeconomic importance (Silva et al., 2013). However, studies have shown undesirable percentages of thermotolerant coliforms indicating poor storage, inadequate hygienic conditions during cultivation and handling and fecal contamination (Silva et al., 2016), which requires its sanitization with antimicrobial agents in order to ensure and maintain microbiological quality at safe and efficient levels (Beuchat et al., 2001). Thus, the aim of this study was to evaluate the potential application of LAEO and CCEO as natural sanitizers in coriander.

\section{Material and methods}

\subsection{Extraction and characterization of EOs}

The aerial parts of Lippia alba (Mill) and Cymbopogon citratus D.C. Stapf. species (800 $\mathrm{g}$ of each) were collected in the

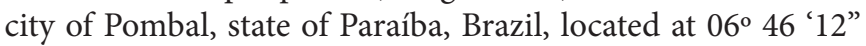
South latitude and $37^{\circ} 48^{\prime} 07^{\prime \prime}$ West longitude, between January and March 2016 in the evening, since this is the period of the highest active principle concentration of plants, as well as better yields in production (Manganotti et al., 2011). Next, they were transported to the Laboratory of Grain and Cereals Technology, UFCG - Pombal for EO extraction by hydrodistillation in a Clevenger extractor (Farmacopéia Brasileira, 1988) for 3 hours at an approximate temperature of $80^{\circ} \mathrm{C}$. The yield of each extracted EO was then calculated (Fonseca \& Librand, 2008).

Total phenolic components of the EOs were determined using Folin-Ciocalteu and gallic acid as standards, with absorbance measured at $765 \mathrm{~nm}$ (Singleton et al., 1999). Analyzes were performed in triplicate and expressed as $\mathrm{mg}$ of GAE (Gallic Acid Equivalent) per g of analyzed EO.

\subsection{Obtaining of bacterial strains and preparation of inocula}

The test strains used were Staphylococcus aureus INCQS-00015 (ATCC 25923), Salmonella enterica sorovar Thyphimurium INCQS-00150 (ATCC 14028), Salmonella enterica sorovar Enteritidis INCQS 00258 (ATCC 13076), Escherichia coli INCQS 00219 (ATCC 8739) and Listeria monocytogenes INCQS 00266 (ATCC 7644), which were acquired from the Collection of Reference Microorganisms in Sanitary Surveillance-CMRVS, FIOCRUZ-INCQS, Rio de Janeiro, RJ. Bacterial inocula standardization was performed using the McFarland scale, according to the procedures described by Wiegand et al. (2008), obtaining an initial inoculum of $8 \log \mathrm{CFU} / \mathrm{mL}$.

\subsection{LAEO and CCEO cytotoxicity}

The bioassay with Artemia salina L. was based on the technique described by Meyer et al. (1982). Each test tube contained $5 \mathrm{~mL}$ of saline solution (1:1 seawater and distilled water) plus varying concentrations of EOs (0 to $500 \mu \mathrm{g} / \mathrm{mL}$ ) and ten nauplii. The number count of dead larvae was performed after 24 hours and was used for calculating the LD50 by the linear regression method. The criteria for classifying EO cytotoxicity against Artemia salina L. based on the values found for LD50 was defined by Meyer et al. (1982) and Nguta et al. (2012), where values of $\mathrm{LD} 50>1000 \mu \mathrm{L} / \mathrm{mL}$ are considered non-toxic, those between 500 and $1000 \mu \mathrm{L} / \mathrm{mL}$ are slightly toxic, those between 100 and $500 \mu \mathrm{L} / \mathrm{mL}$ are moderately toxic and those $<100 \mu \mathrm{L} / \mathrm{mL}$ as strongly toxic. The tests were carried out five times.

\subsection{Determination of Minimum Inhibitory Concentration (MIC)}

The broth macrodilution technique was used for determining LAEO and CCEO Minimum Inhibitory Concentration (MIC), in which the test strains were inoculated into brain and heart infusion broth (BHI) and peaked to the surface of test tubes containing Base Agar Blood (BAB), added to increasing doubled concentrations of EOs ( 0 to $10 \mu \mathrm{L} / \mathrm{mL}$ ), and then the tubes were incubated in an oven at $37^{\circ} \mathrm{C}$ for 24 hours, in duplicate. After the incubation period, the lowest $\mathrm{EO}$ concentration that did not show visible microbial growth was considered the minimum inhibitory concentration (Clinical and Laboratory Standards Institute, 2015).

\subsection{Sanitary Potential of LAEO and CCEO against the naturally contaminant microbiota of coriander}

The plant chosen for evaluating the sanitizing power of EOs was coriander (Coriandrum sativum L.), since it is an easily accessible herb with ample production in the Northeast region of Brazil. About 1000 grams of coriander cultivated with agro-ecological form without the use of pesticides were purchased from the open market of Pombal-PB in the month of April of 2016.

Sanitary potential of LAEO and CCEO was evaluated against the naturally contaminant microbiota of coriander, where $200 \mathrm{~g}$ portions were rinsed under running water and submitted to four treatments: $500 \mathrm{~mL}$ of distilled water - positive control; $500 \mathrm{~mL}$ of sodium hypochlorite with $100 \mathrm{ppm}$ free chlorine - negative control; $500 \mathrm{~mL}$ of LAEO aqueous solution at the defined MIC with Tween $20(0.1 \% \mathrm{w} / \mathrm{v})$; or $500 \mathrm{~mL}$ of CCEO aqueous solution at the defined MIC with Tween $20(0.1 \% \mathrm{w} / \mathrm{v})$. The solutions were kept under light agitation for $5 \mathrm{~min}$ at $28^{\circ} \mathrm{C}$ in order to ensure homogenization of the solutions and complete immersion of the herbs/leaves during the treatments. Next, the samples were then taken from the different solutions and stored in plastic trays, covered with PVC film and kept under refrigeration for $48 \mathrm{~h}$ (Souza et al., 2009). The sanitizing potential of the EOs on coriander during storage was determined at different time intervals $(0,24$ and $48 \mathrm{~h})$ by evaluating the presence of coliforms at $45^{\circ} \mathrm{C}, \mathrm{S}$. aureus and Salmonella spp., according to 
the methodology described by Silva et al. (2010) to evaluate the behavior of sanitizers during storage.

\subsection{Statistical analysis}

LD50 (the dose required to kill 50\% of the A. salina L. nauplii population) determination was based on the PROBIT analysis (Finney, 1962) using the BioStat ${ }^{\circledast}$ software (2009) with $95 \%$ confidence. For the MIC determination assays, the results were expressed as modal values. Statistical analysis was performed to determine significant differences $(\mathrm{p}<0.05)$ using ANOVA with OriginPro8:

\section{Results and discussion}

\subsection{EO characterization}

The evaluated EOs presented higher extraction yield (Table 1) than that reported in the literature for the maximum values LAEO 0.54\% (Nogueira et al., 2007) and similar to that reported by Koshima et al. (2006), 0.55\% to CCEO, which was related to variables such as seasonality, plant development, and temperature, among other factors (Gobbo-Neto \& Lopes, 2007). The EOs presented densities above $0.90 \mathrm{~g} / \mathrm{mL}$.

Total phenolic contents were 15.29 and $18.81 \mathrm{mg}$ of GAE/g for LAEO and CCEO, respectively, which was related to the antimicrobial capacity of these components (Shan et al., 2007), as they have the ability to go through and disintegrate cell membranes, and their bioactivity is linked to this mechanism (Naidu, 2000).

Port's et al. (2013) studying herbal infusions from the Amazonian region of Brazil met values of 27.37 and $13.61 \mathrm{mg} \mathrm{GAE} / \mathrm{g}$ for infuse Lippia alba and Cymbopogon citratus, respectively, demonstrating value above the determined to LAEO and below to CCEO.

\subsection{LAEO and CCEO cytotoxicity}

LAEO had biological activity against Artemia salina L. with LD50 of $41.56(\mu \mathrm{g} / \mathrm{mL})$, and with limits varying from 29.32 to $62.38(\mu \mathrm{g} / \mathrm{mL})$. CCEO presented LD50 of $18.85(\mu \mathrm{g} / \mathrm{mL})$, with limits ranging from 13.71 to $26.00(\mu \mathrm{g} / \mathrm{mL})$. The results showed that the EOs present high toxicity to Artemia salina and may consider bioassay as a preliminary means to determine the bioavailability of the EOs and not the real toxicity of the product. Some authors have reported LD 50 values below $250 \mu \mathrm{g} / \mathrm{mL}$ with anticancer, antifungal, antiviral, antimicrobial, insecticide and trypanosomicide (Nguta et al., 2012; Meyer et al., 1982; Macrae et al., 1988; Siqueira et al., 1998).

Table 1. Physico-chemical characteristics of of Lippia alba (Mill) (LAEO) and Cymbopogon citratus D.C. Stapf. (CCEO) essential oils.

\begin{tabular}{lcc}
\hline \multicolumn{1}{c}{ Physical characteristics } & LAEO & CCEO \\
\hline Yield $(\% \mathrm{v} / \mathrm{m})$ & 0.65 & 0.54 \\
Density at $20{ }^{\circ} \mathrm{C}(\mathrm{g} / \mathrm{mL})$ & 0.94 & 0.98 \\
Total phenolics $(\mathrm{mg}$ of GAE/g of EO $\pm \mathrm{SD})$ & $18.81 \pm 0.15$ & $15.29 \pm 0.69$ \\
\hline
\end{tabular}

Legend: GAE - gallic acid; EO - essential oil; SD - standard deviation.

\subsection{Sanitary potential of LAEO and CCEO}

LAEO and CCEO had activity on microorganisms assayed with MIC ranging from 1.25 to $5.00 \mu \mathrm{L} / \mathrm{mL}$ and 0.62 to $1.25 \mu \mathrm{L} / \mathrm{mL}$, respectively (Table 2). According to Aligiannis et al. (2001), based on the MIC of plant extracts we can classify their inhibition profiles as: strong inhibitors, with MIC up to $500 \mu \mathrm{g} / \mathrm{mL}$; moderate inhibitor - MIC between 600 and $1500 \mu \mathrm{g} / \mathrm{mL}$; and weak inhibitor, with MIC greater than $1500 \mu \mathrm{g} / \mathrm{mL}$. Thus, LAEO and CCEO may be regarded as strong microbial and potentially bioactive inhibitors. The MIC values for CCEO are in agreement with those found by Leite et al. (2016) in evaluating CCEO antimicrobial activity on E. coli, L. monocytogenes and Salmonella Enteritidis in pineapple juice.

The CCEO presented lower MIC values than those of LAEO, corroborating with the bioactivity observed in the cytotoxicity for Artemia salina L, where it also presented lower values of LD50. We can verify that the highest MIC values were observed for E. coli, followed by MIC values related to the two Salmonella serovars, especially in LAEO, which may be related to the structural characteristic of the cell wall presented by the gram-negative bacteria. According to Hyldgaard et al. (2012), gram-negative bacteria are generally less sensitive to the antimicrobial action than gram-positive bacteria. This occurs due to the action of the essential oils mainly occurring in the cell wall of the strains, which would require a higher concentration of the antimicrobial agent for inhibiting a gram-negative bacterium.

By determining cytotoxicity and minimum inhibitory concentration, EO application in safe and effective doses can be recommended. The MIC used for the application of LAEO and CCEO in sanitizing coriander was the lowest concentration of inhibition among all strains, corresponding to 1.25 and $0.62 \mu \mathrm{L} / \mathrm{mL}$ (Table 2), respectively, with the purpose of verifying its real efficiency when tested against naturally contaminant coriander microflora (Figure 1).

The microbiological analyzes performed on the coriander found the presence of coliforms at $45^{\circ} \mathrm{C}$, and $S$. aureus, as well as the absence of Salmonella spp. RDC Number 12 (Brasil, 2001) only requires the evaluation of the presence or absence of Salmonella spp./25 g for in natura vegetables/greens, considering that the food is fit for consumption as it meets the absence pattern of Salmonella spp. established by the legislation in force, although the presence of $S$. aureus pose potential health risks to consumers.

In Figure 1 we have the results of counts for $S$. aureus in coriander with different sanitizers during storage. The counts

Table 2. Minimum Inhibitory Concentration of Lippia. alba (Mill) (LAEO) and Cymbopogon citratus D.C. Stapf (CCEO) essential oils against important microorganisms in food.

\begin{tabular}{lcc}
\hline \multirow{2}{*}{ Test Microorganisms } & \multicolumn{2}{c}{$\mathrm{MIC}(\mu \mathrm{L} / \mathrm{mL})$} \\
\cline { 2 - 3 } & LAEO & CCEO \\
\hline Staphylococcus aureus (ATCC 25923) & 1.25 & 0.62 \\
Salmonella Thyphimurium (ATCC 14028) & 2.50 & 0.62 \\
Salmonella Enteritidis (ATCC 13076) & 2.50 & 0.62 \\
Escherichia coli (ATCC 8739) & 5.00 & 1.25 \\
Listeria monocytogenes (ATCC 7644) & 1.25 & 0.62 \\
\hline
\end{tabular}



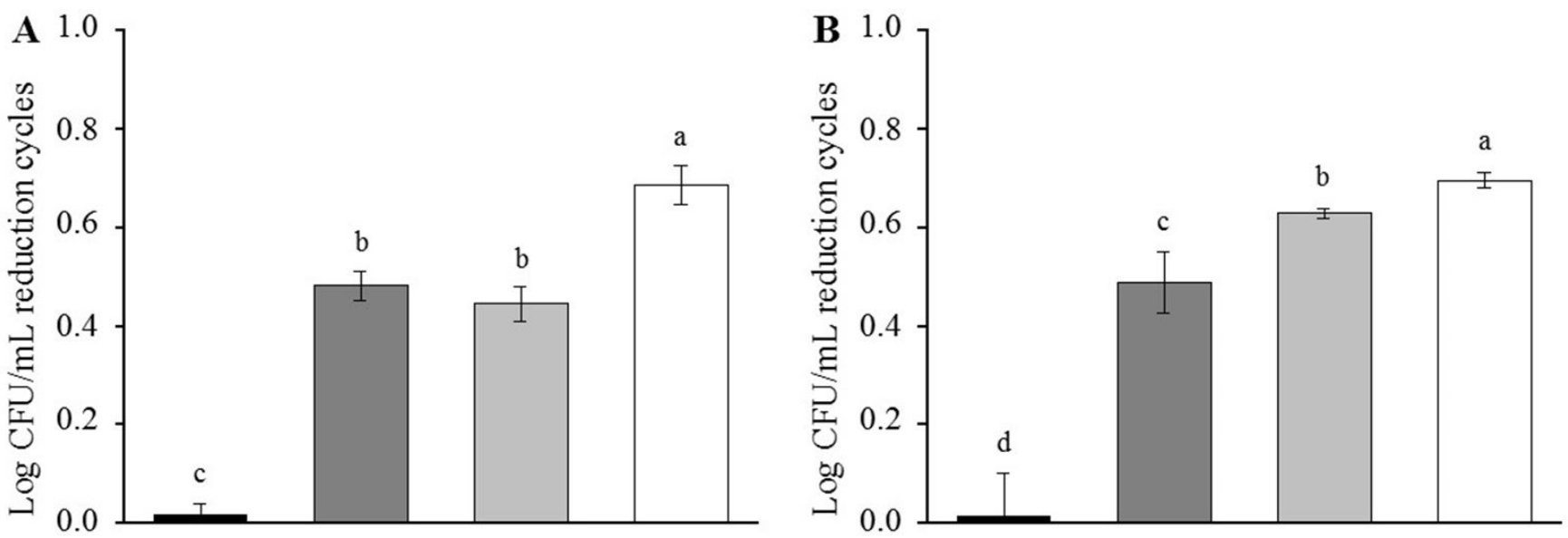

Figure 1. Reduction cycles $(\log 10 \mathrm{CFU} / \mathrm{mL})$ of the initial viable cell counts of $S$. aureus ATCC 25923 in coriander as a function of different treatments: water, sodium hypochlorite, Lippia alba (Mill) (LAEO; $\left.1.25 \mu \mathrm{L} \mathrm{mL}^{-1}\right)$ and Cymbopogon citratus D.C. Stapf. (CCEO; $\left.0.62 \mu \mathrm{L} \mathrm{mL}^{-1}\right)$; after 24 (A) and $48 \mathrm{~h}(\mathrm{~B})$ of storage at $4 \pm 0.5^{\circ} \mathrm{C}$ (black bars: reductions observed in control assays - water; grey bars: reductions caused by sodium hypochlorite; light grey bars: reductions caused by LAEO; white bars: reductions caused by CCEO).

were made based on reduction of initial count (zero storage time) cycles and 24 and 48 hours storage times of coriander under refrigeration. After 24 hours storage it is observed that treatment with CCEO was superior to treatment with sodium hypochlorite, whereas treatment with LAEO was statistically similar. This shows that even at low concentrations the EOs were efficient and that the sanitizing potential of the two increases with the passage of storage time.

Evaluating coliform counts at $45^{\circ} \mathrm{C}$ during storage, it was observed that samples that were immersed in water had values of 3.6 NMP g ${ }^{-1}$ for time zero and $9.1 \mathrm{NMP} \mathrm{g}^{-1}$ for the 48 hours storage time. Already samples with sodium hypochlorite treatment showed similar values to LAEO treatment with values of 3.6 $\mathrm{NMP} \mathrm{g}^{-1}$ for time zero and $<3.0 \mathrm{NMP} \mathrm{g}^{-1}$ with 48 hours of storage. While samples with CCEO treatment showed counts of $<3.0 \mathrm{NMP} \mathrm{g}^{-1}$ already at time zero, this count remained in the samples for the times of 24 and 48 hours.

The MIC values used to evaluate the EOs' sanitizing potential were effective in reducing coliform levels at $45{ }^{\circ} \mathrm{C}$ present in coriander at higher (CCEO) or equivalent (LAEO) levels to those achieved by the commercial sanitizer sodium hypochlorite for the same evaluated microorganisms.

This data is relevant, since sodium hypochlorite is the commercial sanitizer of choice for sanitizing fruits and vegetables, and the studied EOs behaved with superior or equivalent efficacy to this commercially available sanitizing agent, as opposed to that found by Hyldgaard et al. (2012), where it is emphasized that the use of EOs as preservatives in foods has been limited because in practice higher concentrations of EOs are required to achieve the observed antimicrobial activity in vitro. However, the data presented in this study corroborate those reported by Leite et al. (2016), where CCEO was efficient in inactivating E. coli, L. monocytogenes and Salmonella Enteritidis in pineapple juice.

Some authors have reported the use of Thymus vulgaris L. (time), Origanum vulgare L. (oregano) and Rosmarinus officinalis L. (rosemary) for antiseptic and sanitizing purposes in vegetables, unveiling the potential use of these substances in foods (Azerêdo et al., 2011; Souza et al., 2013; Oliveira et al., 2015; Siroli et al., 2015; Medeiros Barbosa et al., 2016). Azerêdo et al. (2011) and Souza et al. (2013) used Origanum vulgare L. and Rosmarinus officinalis L. EOs against microorganisms from minimally processed vegetables and in vegetable broth, they concluded that these EOs combined at sub-inhibitory concentrations were efficient in inhibiting the growth and survival of pathogenic and deteriorating microorganisms associated with minimally processed vegetables, being still sensorially acceptable and a potential alternative to replace synthetic sanitizers applied classically in vegetables, respectively. Oliveira et al. (2015) studied the effect of synergistic use of carvacrol and 1-8 cineol (major components of some EOs) against bacteria related to minimally processed vegetables, they concluded that in sub-inhibitory concentrations EOs were effective in inhibiting the growth and survival of L. monocytogenes, A. hydrophila and P. fluorescens in mixed culture. They also concluded that the EOs were responsible for decreasing cell viability, as it altered membrane permeability causing ultrastructural changes in the cells tested.

We found that the microbial counts decreased throughout the exposure period to LAEO and CCEO, demonstrating an increase in the efficiency of EOs as a function of time. The CCEO achieved greater microbial inhibition efficiency for all evaluated treatments. The food exposure time to the EOs, effective in reducing the microbial load of spoilage and pathogenic microorganisms, has also been observed by Sousa et al. (2012) and Medeiros Barbosa et al. (2016). The same was observed by Oliveira et al. (2015) when studying the synergistic inhibition of plant-associated bacteria in mixed culture by the major components of EOs, carvacrol and 1,8-cineol.

Although the EO concentrations applied to coriander were lower than the MICs observed in the in vitro tests for E. coli (Table 2), the inhibition of this microorganism can be observed by direct contact with the CCEO at time 0 , or within 24 hours for 
LAEO, demonstrating high potential for the practical application of these EOs in foods.

\section{Conclusion}

LAEO and CCEO reduced the microbial load present in coriander, demonstrating their potential as natural sanitizers and demonstrating superior or equivalent efficacy to $100 \mathrm{ppm}$ sodium hypochlorite, a common commercially used sanitizer. By correlating the cytotoxic and antimicrobial results obtained, the EOs presented potential to be applied to food.

\section{References}

Aguiar, J. S., Costa, M. C. C. D., Nascimento, S. C., \& Sena, K. X. F. R. (2008). Atividade antimicrobiana de Lippia alba (Mill.) N. E. Brown (Verbenaceae). Revista Brasileira de Farmacognosia, 18(3), 436-440. http://dx.doi.org/10.1590/S0102-695X2008000300018.

Aligiannis, N., Kalpoutzakis, E., Mitaku, S., \& Chinou, I. B. (2001). Composição e atividade antimicrobiana de óleos essenciais de duas espécies de Origanum. Journal of Agricultural and Food Chemistry, 49, 4168-4170. http://dx.doi.org/10.1021/jf001494m. PMid:11559104.

Almeida, A. C., Morão, R. P., Martins, E. R., Fonseca, F. S. A., Souza, C. N., Prates, J. P. B., Oliveira, F. D., \& Silva, L. M. V. (2016). Atividade antisséptica do óleo essencial de Lippia origanoides Cham. (Alecrimpimenta) na presença de leite bovino. Pesquisa Veterinária Brasileira, 36(9), 905-911. http://dx.doi.org/10.1590/s0100-736x2016000900018.

Azerêdo, G. A., Stamford, T. L. M., Nunes, P. C., Gomes, N. J. No, Oliveira, M. E. G., \& Souza, E. L. (2011). Combined application of essential oils from Origanum vulgare L. and Rosmarinus officinalis L. to inhibit bacteria and autochthonous microflora associated with minimally processed vegetables. Food Research International, 44(5), 1541-1548. http://dx.doi.org/10.1016/j.foodres.2011.04.012.

Bakkali, F., Averbeck, S., Averbeck, D., \& Idaomar, M. (2008). Biological effects of essential oils - A review. Food and Chemical Toxicology, 46(2), 446-475. http://dx.doi.org/10.1016/j.fct.2007.09.106. PMid:17996351.

Bassolé, I. H. N., Lamien-Meda, A., Bayala, B., Obame, L. C., Ilboudo, A. J., Franz, C., Novak, J., Nebié, R. C., \& Dicko, M. H. (2011). Chemical composition and antimicrobial activity of Cymbopogon citratus and Cymbopogon giganteus essential oils alone and in combination. Phytomedicine, 18(12), 1070-1074. http://dx.doi. org/10.1016/j.phymed.2011.05.009. PMid:21665450.

Beuchat, L. R., Farber, J. M., Garrett, E. H., Harris, L. J., Parish, M. E., Suslow, T. V., \& Busta, F. F. (2001). Standardization of a method to determine the efficacy of sanitizers in inactivating human pathogenic microorganisms on raw fruit and vegetables. Journal of Food Protection, 64(7), 1079-1084. http://dx.doi.org/10.4315/0362028X-64.7.1079. PMid:11456197.

Boukhatem, M. N., Ferhat, M. A., Kameli, A., Saidi, F., \& Kebir, H. T. (2014). Lemon grass (Cymbopogon citratus) essential oil as a potent anti-inflammatory and antifungal drugs. The Libyan Journal of Medicine, 9(1), 1-10. http://dx.doi.org/10.3402/ljm.v9.25431.

Brasil. Ministério da Saúde. Agência Nacional de Vigilância Sanitária. (2001, January 2). Resolução no 12 , de 02 de janeiro de 2001. Aprova o regulamento técnico sobre padrões microbiológicos para alimentos. Diário Oficial [da] República Federativa do Brasil.

Burt, S. (2004). Essential oils: their antibactericidal properties and potential application in food - a review. International Journal of Food Microbiology, 94(3), 223-253. http://dx.doi.org/10.1016/j. ijfoodmicro.2004.03.022. PMid:15246235.
Clinical and Laboratory Standards Institute - CLSI. (2015). Methods for Dilution Antimicrobial Susceptibility Tests for Bacteria that Grow Aerobically, CLSI Document M07-A10 (10th ed.). Pennsylvania: Clinical and Laboratory Standards Institute.

Farmacopéia Brasileira, I. V. (1988). Parte 1 (5. ed). São Paulo: Editora Atheneu.

Finney, D. J. (1962). Probit Analysis (2. ed.). London: Cambridge University Press.

Fonseca, P., \& Librand, A. P. L. (2008). Evaluation of physico-chemical and phytochemical characteristics of different tinctures of barbatimão (Stryphnodendron barbatiman). Brazilian Journal of Pharmaceutical Sciences, 44, 271-277.

Gobbo-Neto, L., \& Lopes, N. P. (2007). Plantas medicinais: fatores de influência no conteúdo de metabólitos secundários. Quimica Nova, 30(2), 374-381. http://dx.doi.org/10.1590/S0100-40422007000200026.

Gómez-López, V. M., Ragaert, P., Jeyachchandran, V., Debevere, J., \& Devlieghere, F. (2008). Shelf-live of minimally processed lettuce and cabbage treated with gaseous chlorine dioxide and cysteine. International Journal of Food Microbiology, 121(1), 74-83. http:// dx.doi.org/10.1016/j.ijfoodmicro.2007.11.036. PMid:18077040.

Guimarães, L. G. L., Cardoso, M. G., Sousa, P. E., Andrade, J., \& Vieira, S. S. (2011). Atividades antioxidante e fungitóxica do óleo essencial de capim-limão e do citral. Revista Ciência Agronômica, 42(2), 464472. http://dx.doi.org/10.1590/S1806-66902011000200028.

Hyldgaard, M., Mygind, T., \& Meyer, R. L. (2012). Essential oils in food preservation: mode of action, synergies, and interactions with food matrix components. Frontiers in Microbiology, 3(12), 1-24. PMid:22291693.

Jezler, C. N., Oliveira, A. R. M. F., Batista, R. S., Oliveira, R. A., Silva, D. C., \& Costa, L. C. B. (2013). Lippia alba morphotypes cidreira and melissa exhibit significant differences in leaf characteristics and essential oil profile. Revista Brasileira de Farmacognosia, 23(2), 217-223. http://dx.doi.org/10.1590/S0102-695X2013005000008.

Koshima, F. A. T., Ming, L. C., \& Marques, M. O. M. (2006). Produção de biomassa, rendimento de óleo essencial e de citral em capim-limão, Cymbopogon citratus (DC.) Stapf, com cobertura morta nas estações do ano. Revista Brasileira de Plantas Medicinais, 8(4), 112-116.

Leite, C. J., Sousa, J. P., Medeiros, J. A., Conceição, M. L., Santos FalcãoSilva, V., \& Souza, E. L. (2016). Inactivation of Escherichia coli, Listeria monocytogenes and Salmonella Enteritidis by Cymbopogon citratus D.C. Stapf. Essential Oil in Pineapple Juice. Journal of Food Protection, 79(2), 213-219. http://dx.doi.org/10.4315/0362-028X. JFP-15-245. PMid:26818981.

Lermen, C., Morelli, F., Gazim, Z. C., Silva, A. P., Gonçalves ,, J. E., Dragunski, D. C., \& Albertona, O. (2015). Essential oil content and chemical composition of Cymbopogon citratus inoculated with arbuscular mycorrhizal fungi under different levels of lead. Industrial Crops and Products, 76, 734-738. http://dx.doi.org/10.1016/j. indcrop.2015.07.009.

Macrae, W. D., Hudson, J. B., \& Towers, G. H. (1988). Studies on the pharmacological activity of Amazonian Euphorbiaceae. Journal of Ethnopharmacology, 22(2), 143-172. PMid:3374150.

Manganotti, S. A., Souza, M. F. S., Souza, P. N. S., Meira, M. R., Matos, C. C., \& Martins, E. R. (2011). Influência do horário de coleta, orientação geográfica e dossel na produção de óleo essencial de Cordia verbenácea DC. Biotemas, 24(1), 9-14.

Medeiros Barbosa, I., Costa Medeiros, J. A., Oliveira, K. Á. R., GomesNeto, N. J., Tavares, J. F., Magnani, M., \& de Souza, E. L. (2016). Efficacy of the combined application of oregano and rosemary essential oils for the control of Escherichia coli, Listeria monocytogenes and 
Salmonella Enteritidis in leafy vegetables. Food Control, 59, 468-477. http://dx.doi.org/10.1016/j.foodcont.2015.06.017.

Meyer, B. N., Ferrigni, N. R., Putnam, J. E., Jacobsen, L. B., Nichols, D. E., \& McLaughlin, J. L. (1982). Brine shrimp, a conveniente general bioassy for active-plant constituints. Planta Medica, 45(05), 31-34. http://dx.doi.org/10.1055/s-2007-971236.

Naidu, A. S. (2000). Natural food antimicrobial systems. (p. 818). Boca Raton: CRC Press. http://dx.doi.org/10.1201/9781420039368.

Nguta, J. M., Mbaria, J. M., Gakuya, D. W., Gathumbi, P. K., Kabasa, J. D., \& Kiama, S. G. (2012). Evaluation of Acute Toxicity of Crude Plant Extracts from Kenyan Biodiversity using Brine Shrimp, Artemia salina L. (Artemiidae). The Open Conference Proceedings Journal, 3 , 30-34. http://dx.doi.org/10.2174/2210289201203010030.

Nogueira, M. A., Diaz, G., \& Sakumo, L. (2007). Caracterização química e atividade biológica do óleo essencial de Lippia alba cultivada no Paraná. Revista de Ciências Farmacêuticas Básica e Aplicada, 28(3), 273-278.

Oliveira, D. R., Leitão, G. G., Santos, S. S., Bizzo, H. R., Lopes, D., Alviano, C. S., Alviano, D. S., \& Leitão, S. G. (2006). Ethnopharmacological study of two Lippia species from Oriximiná, Brazil. Journal of Ethnopharmacology, 108(1), 103-108. http://dx.doi.org/10.1016/j. jep.2006.04.018. PMid:16784826.

Oliveira, K. Á. R., Sousa, J. P., Costa Medeiros, J. A., Figueiredo, R. C. B. Q., Magnani, M., Siqueira, J. P., \& Souza, E. L. (2015). Synergistic inhibition of bacteria associated with minimally processed vegetables in mixed culture by carvacrol and 1,8- cineole. Food Control, 47, 334-339. http://dx.doi.org/10.1016/j.foodcont.2014.07.014.

Oliveira, O. R., Terao, D., Carvalho, A. N. P. P., Innecco, R., \& Albuquerque, C. C. (2008). Efeito de óleos essenciais de plantas do gênero Lippia sobre fungos contaminantes encontrados na micropropagação de plantas. Revista Ciência Agronômica, 39(1), 94-100.

Peixoto, M. G., Bacci, L., Blank, A. F., Araújo, A. P. A., Alves, P. B., Silva, J. H. S., Santos, A. A., Oliveira, A. P., Costa, A. S., \& Arrigoni-Blank, M. F. (2015). Toxicity and repellency of essential oils of Lippia alba chemotypes and their major monoterpenes against stored grain insects. Industrial Crops and Products, 71, 31-36. http://dx.doi. org/10.1016/j.indcrop.2015.03.084.

Port's, P. S., Chisté, R. C., Godoy, H. T., \& Prado, M. A. (2013). The phenolic compounds and the antioxidant potential of infusion of herbs from the Brazilian Amazonian region. Food Research International, 53(2), 875-881.

Queiroz, M. R. A., Almeida, A. C., Andrade, V. A., Lima, T. S., Martins, E. R., Figueiredo, L. S., \& Careli, R. T. (2014). Avaliação da atividade antibacteriana do óleo essencial de Lippia organoides frente à Staphylococcus sp. isolados de alimentos de origem animal. Revista Brasileira de Plantas Medicinais, 16(3), 737-743. http://dx.doi. org/10.1590/1983-084x/13_083.

Shan, B., Cai, Y. Z., Brooks, J. D., \& Corke, H. (2007). The in vitro antibacterial activity of dietary spice and medicinal herb extracts. International Journal of Food Microbiology, 117(1), 112-119. http:// dx.doi.org/10.1016/j.ijfoodmicro.2007.03.003. PMid:17449125.

Sharma, P. R., Mondhe, D. M., Muthiah, S., Pal, H. C., Shahi, A. K., Saxena, A. K., \& Qazi, G. N. (2009). Anticancer activity of an essential oil from Cymbopogon flexuosus. Chemico-Biological Interactions, 179(2-3), 160-168. http://dx.doi.org/10.1016/j.cbi.2008.12.004. PMid:19121295.

Silva, A. F. S., Lima, C. A., Queiroz, J. J. F., Jácome, P. R. L. A., \& JácomeJúnior, A. T. (2016). Análise bacteriológica das águas de irrigação de horticulturas. Ambiente \& Água - An Interdisciplinary. Journal of Applied Sciences (Faisalabad), 11, 428-438.

Silva, N., Junqueira, V. C. A., Silveira, N. F. A., Taniwaki, M. H., Santos, R. F. S., \& Gomes, R. A. R. (2010). Manual de Métodos de Análise
Microbiológica de Alimentos e Água (4. ed., Vol. 1, pp. 632). São Paulo: Livraria Varela.

Silva, V. P. R., Tavares, A. L., \& Sousa, I. F. (2013). Evapotranspiração e coeficientes de cultivo simples e dual do coentro. Horticultura Brasileira, 31(2), 255-259. http://dx.doi.org/10.1590/S010205362013000200013.

Singleton, V. L., Orthofer, R., \& Lamuela-Raventos, R. M. (1999). Analysis of total phenols and other oxidation substrates and antioxidants by means of Folin-Ciocalteu Reagent. Methods in Enzymology, 299, 152-178. http://dx.doi.org/10.1016/S0076-6879(99)99017-1.

Siqueira, M. J., Bomm, D. M., Pereira, G. F. N., Garcez, S. W., \& Boaventura, M. A. D. (1998). Estudo fitoquímico de Unonopsis lindmanii - Annonaceae, biomonitorado pelo ensaio de toxicidade sobre Artemia salina Leach. Quimica Nova, 21(5), 557-559. http:// dx.doi.org/10.1590/S0100-40421998000500004.

Siroli, L., Patrignani, F., Serrazanetti, D. I., Tabanelli, G., Montanari, C., Gardini, F., \& Lanciotti, R. (2015). Lactic acid bacteria and natural antimicrobials to improve the safety and shelf-life of minimally processed sliced apples and lamb's lettuce. Food Microbiology, 47, 74-84. http://dx.doi.org/10.1016/j.fm.2014.11.008. PMid:25583340.

Soares, B. V., Neves, L. R., Oliveira, M. S. B., Chaves, F. C. M., Dias, M. K. R., Chagas, E. C., \& Tavares-Dias, M. (2016). Antiparasitic activity of the essential oil of Lippia alba on ectoparasites of colossoma macropomum (tambaqui) and its physiological and histopathological effects. Aquaculture, 452, 107-114. http://dx.doi.org/10.1016/j. aquaculture.2015.10.029.

Sousa, J. P., Azerêdo, G. A., Araújo Torres, R., Silva Vasconcelos, M. A., Conceição, M. L., \& Souza, E. L. (2012). Synergies of carvacrol and 1,8-cineole to inhibit bacteria associated with minimally processed vegetables. International Journal of Food Microbiology, 154(3), 145-151. http://dx.doi.org/10.1016/j.ijfoodmicro.2011.12.026. PMid:22273461.

Souza, E. L., Azerêdo, G. A., Sousa, J. P., Figueiredo, R. C. B. Q., \& Stamford, T. L. M. (2013). Cytotoxic effects of Origanum vulgare L. and Rosmarinus officinalis L. essential oils alone and combined at sublethal amounts on Pseudomonas fluorescens in a vegetable broth. Journal of Food Safety, 33(2), 163-171. http://dx.doi.org/10.1111/ jfs. 12036.

Souza, E. L., Barros, J. C. B., Conceição, M. L., Gomes, N. J. No, \& Costa, A. C. V. (2009). Combined application of Origanum vulgare L. essential oil and acetic acid for controlling the growth of Staphylococcus aureus in foods. Brazilian Journal of Microbiology, 40(2), 387-393. http:// dx.doi.org/10.1590/S1517-83822009000200032. PMid:24031377.

Tohidi, B., Rahimmalek, M., \& Arzani, A. (2017). Essential oil composition, total phenolic, flavonoid contents, and antioxidant activity of Thymus species collected from diferente regions of Iran. Food Chemistry, 220, 153-161. http://dx.doi.org/10.1016/j. foodchem.2016.09.203. PMid:27855883.

U. S. Food and Drug Administration - USFDA. (2017). Title 21 - Food and Drugs. Part 182 - Substances generally recognized as safe. Essential oils, oleoresins (solvent-free), and natural extractives (including distillates). Silver Spring: FDA. Available in: <http://www.accessdata. fda.gov/scripts/cdrh/cfdocs/cfcfr/CFRSearch.cfm?fr=182.20>. Access in: 03 set. 2018.

Valeriano, C., Piccoli, R. H., Cardoso, M. G., \& Alves, E. (2012). Antimicrobial activity of essential oils against sessile and planktonic pathogens of food source. Revista Brasileira de Plantas Medicinais, 4(1), 57-67. http://dx.doi.org/10.1590/S1516-05722012000100009.

Wiegand, I., Hilpert, K., \& Hancock, R. E. W. (2008). Agar and broth dilution methods to determine the minimal inhibitory concentration (MIC) of antimicrobial substances. Nature Protocols, 3(2), 163-175. http://dx.doi.org/10.1038/nprot.2007.521. PMid:18274517. 